\title{
The Neurotensin Agonist PDI49I63 Increases Fos Expression in the Prefrontal Cortex of the Rat
}

\author{
Kimberly A Petrie', Michael Bubser', Cheryl D Casey', M Duff Davis², Bryan L Roth ${ }^{3}$ and Ariel Y Deutch*, \\ 'Departments of Psychiatry and Pharmacology, Center for Molecular Neuroscience, Vanderbilt University Medical Center, Nashville, TN, USA; \\ ${ }^{2}$ CNS Pharmacology, Pfizer Inc., Ann Arbor, MI, USA; ${ }^{3}$ Department of Biochemistry and NIMH Psychoactive Drug Screening Program, Case \\ Western Reserve University, Cleveland, $\mathrm{OH}$, USA
}

\begin{abstract}
Dopaminergic axons innervating the prefrontal cortex (PFC) target both pyramidal cells and GABAergic interneurons. Many of these dopamine (DA) axons in the rat coexpress the peptide neurotransmitter neurotensin. Previous electrophysiological data have suggested that neurotensin activates GABAergic interneurons in the PFC. Activation of D2-like DA receptors increases extracellular GABA levels in the PFC, as opposed to the striatum, where D2 receptor activation inhibits GABAergic neurons. Because activation of presynaptic $D_{2}$ release-modulating autoreceptors in the PFC suppresses DA release but increases release of the cotransmitter neurotensin, D2 agonists may enhance the activity of GABAergic interneurons via release of neurotensin. In order to determine if neurotensin can activate GABAergic interneurons, we treated rats with the peptide neurotensin agonist, PDI49/63, and examined Fos expression in PFC neurons. Systemic administration of PDI49/63 increased overall Fos expression in the PFC, but not in the dorsal striatum. PDI49/63 induced Fos in PFC interneurons, as defined by the presence of calcium-binding proteins, and in pyramidal cells. Pretreatment with the high-affinity neurotensin antagonist, SR48692, blocked neurotensin agonist-induced Fos expression. These data suggest that neurotensin activates interneurons in the PFC of the rat.

Neuropsychopharmacology (2004) 29, 1878-1888, advance online publication, 19 May 2004; doi:I0.1038/sj.npp. 1300494
\end{abstract}

Keywords: dopamine; GABA; interneuron; neurotensin receptor; PDI49I63; SR48692

\section{INTRODUCTION}

The dopaminergic innervation of the prefrontal cortex (PFC) plays an important role in the processing and subsequent integration of cognitive, affective, and even sensory events (Cohen et al, 2002; Goldman-Rakic, 2002; Miller et al, 2002). The targets of the prefrontal cortical dopamine (DA) innervation include both GABAergic interneurons and glutamatergic pyramidal cells (Sesack et al, 1995a; Verney et al, 1990; Seguela et al, 1988; van Eden et al, 1987). Because local circuit GABA interneurons also synapse with pyramidal cells (DeFelipe and Farinas, 1992), the cortical DA innervation can both directly and indirectly alter pyramidal cell activity and hence overall cortical output.

In vivo microdialysis studies suggest that $\mathrm{DA}$ increases extracellular GABA in the PFC through the activation of

*Correspondence: AY Deutch, Psychiatric Hospital at Vanderbilt, Suite 313, 1601 23rd Avenue South, Nashville, TN 37212, USA, Tel: + I 615327 7080, Fax: + I 615322 1901,

E-mail: ariel.deutch@vanderbilt.edu

Received 23 October 2003; revised 8 March 2004; accepted 19 April 2004

Online publication: 20 April 2004 at http://www.acnp.org/citations/ Npp04200403488/default.pdf
D2-like DA receptors (Petrie et al, 2002; Grobin and Deutch, 1998). Dopamine D2-like but not D1-like agonists increase extracellular GABA levels in the PFC, an effect that is blocked by D2 but not D1 antagonists (Grobin and Deutch, 1998). Although $D_{2}$ receptors are localized to GABA interneurons in the rat PFC (Le Moine and Gaspar, 1998), it seems unlikely that the activation of $\mathrm{D}_{2}$ receptors on interneurons would drive GABA release because the net effect of $\mathrm{D}_{2}$ receptor activation is often inhibitory (Kotecha et al, 2002; Hernandez-Lopez et al, 2000; Huff, 1996).

Dopamine $\mathrm{D}_{2}$ receptors in the rat PFC are also present on presynaptic DA terminals, where they function as releasemodulating autoreceptors (Wolf and Roth, 1987). Activation of these $\mathrm{D}_{2}$ autoreceptors decreases DA release but increases release of the colocalized transmitter neurotensin (NT; see Bean and Roth, 1992). In the PFC, NT is localized exclusively to dopaminergic axons (Studler et al, 1988). Thus, activation of $\mathrm{D}_{2}$ autoreceptors decreases DA release but increases NT release from mesoprefrontal cortical neurons.

The high-affinity NT receptor (NTR1) is coupled to excitatory signal transduction pathways (Yamada et al, 1993). In situ hybridization studies have revealed that many PFC neurons express NTR1 mRNA (Alexander and Leeman, 1998; Nicot et al, 1994). These observations, and the fact 
that $\mathrm{D}_{2}$ autoreceptor activation in the PFC increases NT release, raise the possibility that $D_{2}$-elicited GABA release in the PFC is actually mediated by NT. Audinat et al (1989) reported that NT enhanced GABA-mediated synaptic noise in rat PFC pyramidal cells, suggesting that NT excites GABA interneurons.

GABAergic interneurons in the cortex can be divided into three largely non-overlapping classes based on expression of one of three calcium-binding proteins: parvalbumin (PV), calbindin (CB), or calretinin (CR) (DeFelipe, 1997; Gabbott et al, 1997; Rogers, 1992). In the present study, we assessed the effects of acute administration of the truncated peptide NT agonist, PD149163 (Feifel et al, 2003, 1999; Wustrow et al, 1995), on regional forebrain expression of Fos, a marker of neurons that are metabolically activated, with a particular focus on determining if the NT agonist activates prefrontal cortical GABAergic interneurons. Because the binding profile of PD149163 has not been extensively characterized, we also conducted a full screen of receptors to which PD149163 binds.

\section{MATERIALS AND METHODS}

\section{PD149163 Binding Assay}

PD149163 (Chemical Synthesis Branch of NIMH, NIH) was screened against a large number of cloned G-proteincoupled receptors, ion channels, and transporters, as previously described (Shapiro et al, 2003; a full description of the assay conditions can be found at http:// kidb.cwru.edu/nimh/binding.php). Targets for which PD149163 had an affinity of $\leqslant 10000 \mathrm{nM}$ were further characterized using a full curve.

\section{Animals}

Adult male Sprague-Dawley rats weighing 275-345 g (Harlan, Birmingham, AL) were group-housed on a $12 \mathrm{~h}$ light-dark cycle with lights on at 0600 , with food and water available ad libitum. All studies were performed in compliance with the NIH Guide for Care and Use of Laboratory Animals.

\section{Treatments}

To examine the effect of PD149163 on forebrain Fos expression, rats $(n=4$ /group $)$ were injected with PD149163 $(0.05,0.25$, or $2.5 \mathrm{mg} / \mathrm{kg}$, i.p. $)$ or its vehicle (water). After $2 \mathrm{~h}$, the animals were decapitated and the PFC, nucleus accumbens septi (NAS), and dorsolateral striatum (CP) were dissected and stored at $-80^{\circ} \mathrm{C}$ until assayed by Western blots.

Subsequent efforts focused on determining the effects of PD149163 on PFC neurons, using immunohistochemistry to define the type of cells in which Fos was induced. Rats ( $n=5-7 /$ group) were injected with 0.25 or $2.5 \mathrm{mg} / \mathrm{kg}$ PD149163 or vehicle. Other groups of rats were injected with the nonpeptide NTR1 antagonist SR48692 $(1.0 \mathrm{mg} / \mathrm{kg}$, i.p.; Sanofi Recherche, Toulouse, France) or vehicle (1\% Tween 20 in distilled water), followed $30 \mathrm{~min}$ later by $0.25 \mathrm{mg} / \mathrm{kg}$ PD149163 or vehicle; this dose was chosen on the basis of the results from the immunoblot studies. At $2 \mathrm{~h}$ after administration of the NT agonist, animals were anesthetized with isoflurane (Henry Schein, Melville, NY) and their colonic temperatures were recorded as an independent confirmation of the actions of the NT agonist (Bissette et al, 1976). Rats were then transcardially perfused with $4 \%$ paraformaldehyde in $0.1 \mathrm{M}$ phosphate buffer $(\mathrm{pH}$ 7.4), and the brains were removed and post-fixed overnight before being cryoprotected in $24 \%$ sucrose in phosphate buffer. Coronal sections $(42 \mu \mathrm{m})$ were cut through the forebrain on a freezing microtome.

\section{Immunoblot Analyses}

Immunoblot analysis of Fos protein levels was performed using a previously characterized rabbit anti-Fos antibody that was generated against the m peptide (Quinn et al, 1989) and recognizes both Fos and Fos-related antigens (Fras). Tissue samples were homogenized in 2\% SDS and an aliquot was removed to determine protein levels (Lowry et al, 1951). Equal amounts of protein were run on a $10 \%$ acrylamide $/ 0.27 \%$ methylenebisacrylamide gel overnight at $67 \mathrm{~V}$ and were transferred to nitrocellulose. Blots were incubated for $48 \mathrm{~h}$ at $4{ }^{\circ} \mathrm{C}$ in the anti-Fos antibody $(1: 5000)$. The blots were then washed, incubated for $2 \mathrm{~h}$ in horseradish peroxidase-conjugated secondary antibody (Vector Labs, Burlingame, CA; 1:4000), and washed again before being developed using enhanced chemiluminescence.

\section{Immunohistochemistry}

Immunoperoxidase methods followed our previously described avidin-biotin methods (see Deutch and Duman, 1996). Fos was detected using a heavy-metal-intensified diaminobenzidine as the chromogen; double-label studies with MAP-2, a marker for pyramidal cells, or choline acetyltransferase (ChAT), a marker of cholinergic neurons, used a brown diaminobenzidine reaction product to mark MAP-2- or ChAT-positive cells. For immunofluorescent studies, free-floating sections were washed extensively in $50 \mathrm{mM}$ Tris-buffered saline (TBS) and incubated for $60 \mathrm{~min}$ in TBS containing $0.2 \%$ Triton and $4 \%$ normal horse serum. Sections were then incubated for $48 \mathrm{~h}$ at $4{ }^{\circ} \mathrm{C}$ in a solution containing two antibodies, one directed against Fos and the other against one of the three calcium-binding proteins that define cortical interneuron populations. The sections were washed and transferred to a solution containing Cy2- and Cy3-conjugated secondary antibodies (1:1000; Jackson ImmunoResearch, West Grove, PA) for $2 \mathrm{~h}$ at room temperature, then washed extensively, mounted, and coverslipped. The antibodies used included mouse anti-PV (1:1500; Sigma, St Louis, MO), mouse anti-CB (1:3000; Sigma), goat $(1: 2500$; Chemicon, Temecula, CA) or rabbit anti-CR (1:1500; SWANT, Bellinzona, Switzerland), mouse anti-MAP2 (1:400; Sigma), goat anti-ChAT (1:1000; Chemicon) and rabbit (Oncogene, San Diego, CA; 1:7500) or goat anti-Fos (1:2000; Santa Cruz Biotechnology, Santa Cruz, CA).

\section{Cell Counts and Data Analysis}

Fos-like immunoreactive (-li) cells were counted in the deep layers of the prelimbic cortex (area 32) of the PFC, where 
the mixed DA-NT innervation is most dense. The number of Fos-li neurons $/ \mathrm{mm}^{2}$ was determined, and the data were analyzed by ANOVA with post hoc tests when indicated.

To determine the relative induction of Fos in different types of interneurons, images of the deep layers of the prelimbic cortex were captured using a digital camera. Approximately $100 \mathrm{PV}, 100 \mathrm{CB}$, and $50 \mathrm{CR}$-like immunoreactive cells were identified in each animal, and the percentage of these cells in which a Fos-li nucleus was present was determined. The data were analyzed by ANOVA with subsequent Newman-Keuls post hoc tests when indicated.

Finally, Fos expression was assessed in cholinergic neurons of the basal forebrain, which have previously been shown to express NTR1 (Alexander and Leeman, 1998; Boudin et al, 1996; Nicot et al, 1994) and to depolarize in response to NT (Cape et al, 2000; Matthews, 1999; Farkas et al, 1994). We determined the percentage of doublelabeled (Fos + ChAT) cells in the horizontal limb of the diagonal band of Broca (HDB), where the cholinergic cells that project to the PFC are located (Gaykema et al, 1991, 1990; Luiten et al, 1987); in addition, we determined the numbers of Fos-li and double-labeled Fos + ChAT cells in the globus pallidus, where cells that project to the PFC are rarely encountered (Gritti et al, 1997).

\section{RESULTS}

\section{Pharmacological Profile of PD149163}

PD149163 selectively bound to the NTR1 receptor, with a $K_{\mathrm{i}}$ of $159 \mathrm{nM}$ and no affinity for NTR2 (Table 1). With the exception of the sigma-1 and I1-imidazoline receptors, for which PD149163 displayed negligible affinities $\left(K_{\mathrm{i}}=5214\right.$ and $2032 \mathrm{nM}$, respectively), the NT compound exhibited no measurable affinity for any of the other receptors, ion channels, or transporters tested (see Table 1).

\section{Effect of PD149163 on Core Body Temperature}

Systemic treatment with PD149163 dose-dependently reduced core body temperature $\left(\mathrm{F}_{2,18}=29.75 ; p \leqslant 0.0001\right.$; Table 2). The higher dose of the NT agonist reduced temperature by almost $2^{\circ} \mathrm{C}$ compared to vehicle-treated animals. Pretreatment with the NT antagonist SR48692 did not block PD149163-induced hypothermia, nor did it have any effect of its own on body temperature (data not shown).

\section{Effects of PD149163 on the Density of Fos-li Cells in the PFC}

Immunoblot assessment of the effects of PD1491653 on Fos expression was conducted to determine a dose range for the NT agonist, and revealed that PD149163 potently induced Fos and several lower weight Fras in the PFC in a doserelated manner (see Figure 1). The effect of PD149163 on cortical Fos expression was dose-related, with $0.25 \mathrm{mg} / \mathrm{kg}$ appearing to markedly increase Fos relative to vehicle, and the higher $(2.5 \mathrm{mg} / \mathrm{kg})$ dose resulting in a somewhat lesser induction. The NT agonist appeared to induce Fos weakly in the NAS at the $0.25 \mathrm{mg} / \mathrm{kg}$ dose, but had no apparent effect in the striatum at any dose examined.
The ability of the NT agonist to induce Fos in the PFC was confirmed and extended by immunohistochemical studies (Figure 2). ANOVA revealed a significant treatment effect on the density of Fos-li neurons in the PFC $\left(\mathrm{F}_{2,16}=4.52\right.$; $p \leqslant 0.05)$, with a significant increase in the density of Fos-li neurons in animals receiving $0.25 \mathrm{mg} / \mathrm{kg}$, but not $2.5 \mathrm{mg} / \mathrm{kg}$, PD149163. In contrast, analyses did not uncover any significant effect of PD149163 on Fos expression in the nucleus accumbens $\left(\mathrm{F}_{2,16}=2.47 ; p \leqslant 0.05\right)$ or the dorsal striatum $\left(\mathrm{F}_{2,16}=0.82 ; p \leqslant 0.05\right)$, although there was a trend toward an effect in the former site.

In a separate experiment we found that pretreatment with the selective NTR1 antagonist SR48692 blocked the ability of PD149163 to induce Fos in the PFC $\left(\mathrm{F}_{3,27}=6.79\right.$; $p \leqslant 0.005$; Figure 3). Acute administration of SR48692 had no significant effect on the density of Fos-li neurons compared to vehicle.

\section{Effects of PD149163 on Fos Expression in Cortical Interneurons}

PD149163 increased Fos in prefrontal cortical interneurons as well as in MAP-2-li pyramidal cells (Figures 4 and 5). ANOVA revealed a significant treatment effect on Fos induction in PV- $\left(\mathrm{F}_{2,17}=6.90 ; p \leqslant 0.01\right), \mathrm{CR}-\left(\mathrm{F}_{2,18}=5.35\right.$; $p \leqslant 0.05)$, and CB- $\left(\mathrm{F}_{2,19}=4.83 ; p \leqslant 0.05\right)$ containing interneurons (Figure 5). Post hoc analyses showed that Fos was significantly induced in $\mathrm{PV}$-containing interneurons in response to the low but not high dose of the NT agonist. In contrast, only the high dose significantly increased Fos expression in CB-immunoreactive interneurons.

We determined if pretreatment with the NT receptor antagonist SR48692 could attenuate Fos induction in response to PD149163 in specific populations of PFC interneurons (Figure 6). Because $0.25 \mathrm{mg} / \mathrm{kg}$ PD149163 did not increase Fos expression in CB-containing cells (Figure 5), we restricted our analysis to PV- and CRcontaining interneurons. Overall ANOVAs uncovered a significant treatment effect in both $\mathrm{PV}-\left(\mathrm{F}_{3,27}=3.80\right.$; $p \leqslant 0.05)$ and $\mathrm{CR}-\left(\mathrm{F}_{2,26}=17.26 ; p \leqslant 0.0001\right)$ containing interneurons. Fos expression was increased in both PVand CR-containing interneurons by $0.25 \mathrm{mg} / \mathrm{kg}$ PD149163, and pretreatment with the NTR1 antagonist SR48692 blocked the effects of the NT agonist.

\section{Effects of PD149163 on Fos Expression in the Cholinergic Cells of the Basal Forebrain}

Fos expression in the globus pallidus was unaltered by treatment with PD149163 (data not shown). In contrast, PD149163 increased Fos expression in both cholinergic and non-cholinergic cells of the HDB (Figure 7). ANOVA revealed a significant treatment effect of PD149163 on the overall density of Fos-li cells in both the rostral $\left(\mathrm{F}_{2,16}=15.42 ; p \leqslant 0.005\right)$ and caudal $\left(\mathrm{F}_{2,15}=9.86 ; p \leqslant 0.005\right)$ HDB; post hoc analyses revealed that only the higher dose of the NT agonist increased the Fos expression in the caudal HDB, whereas both doses induced Fos in neurons of the rostral HDB. Using an antibody directed against ChAT, we found that PD149163 induced Fos expression in cholinergic neurons in the caudal $\left(\mathrm{F}_{2,15}=6.59 ; p \leqslant 0.001\right)$ but not rostral HDB. 
Table I Affinities of PDI49/63 and Reference Compounds at Various Receptors, Transporters, Channels, and Binding Sites

\begin{tabular}{|c|c|c|c|c|c|}
\hline Receptor & Cold ligand & ${ }^{3} \mathrm{H}$-ligand & $K_{\mathrm{D}}(\mathrm{nM})$ & Assay conc. (nM) & PDI49|63 (nM) \\
\hline NTRI & PDI49|63 & NT & 7 & 3 & 159 \\
\hline NTR2* & NT/levocabastine & NT & 5 & 3 & $>10000$ \\
\hline $5-H T_{\mid A}$ & WAY I00,635 & 8-OH-DPAT & 1 & 0.5 & $>10000$ \\
\hline $5-\mathrm{HT}_{1 \mathrm{~B}}$ & Ergotamine & GRI25743 & 0.3 & 0.3 & $>10000$ \\
\hline $5-H T_{I D}$ & Ergotamine & GRI25743 & 0.3 & 0.3 & $>10000$ \\
\hline $5-\mathrm{HT}_{6}$ & Chlorpromazine & LSD & 1.5 & 1 & $>10000$ \\
\hline SERT & Fluoxetine & Citalopram & 0.8 & 0.5 & $>10000$ \\
\hline$D_{1}$ & SKF38393/fluphenazine & SCH23390 & 0.35 & 0.2 & $>10000$ \\
\hline $\mathrm{D}_{2 \mathrm{~L}}$ & Haloperidol & $\mathrm{N}$-methylspiperone & 0.5 & 0.2 & $>10000$ \\
\hline$\alpha_{\mid A}$ & Urapidil & Prazosin & 0.2 & 0.2 & $>10000$ \\
\hline$\alpha_{\mid B}$ & Corynanthine & Prazosin & 0.2 & 0.2 & $>10000$ \\
\hline$\alpha_{2 A}$ & Oxymetazoline & Clonidine & 2 & 2 & $>10000$ \\
\hline$\alpha_{2 B}$ & Prazosin & Clonidine & 2 & 2 & $>10000$ \\
\hline$\alpha_{2 C}$ & Prazosin & Clonidine & 2 & 2 & $>10000$ \\
\hline$\beta_{1}$ & Atenolol & Pindolol & 0.1 & 0.1 & $>10000$ \\
\hline$\beta_{2}$ & $|\mathrm{Cl}-||8,55|$ & Pindolol & 0.1 & 0.1 & $>10000$ \\
\hline NET & Nortriptyline/imipramine & Nisoxetine & 1.2 & 0.5 & $>10000$ \\
\hline$m_{1}$ & Pirenzepine & QNB & 0.2 & 0.5 & $>10000$ \\
\hline$m_{2}$ & Methoctramine & QNB & 0.2 & 0.5 & $>10000$ \\
\hline MOR & Naloxone & Diprenorphine & 0.2 & 0.2 & $>10000$ \\
\hline DOR & Naltrindole & Diprenorphine & 0.2 & 0.2 & $>10000$ \\
\hline KOR & Naloxone & Bremazocine & 4 & 2 & $>10000$ \\
\hline $\mathrm{H}_{1}$ & Chlorpheniramine & Pyrilamine & 3.6 & । & $>10000$ \\
\hline $\mathrm{H}_{2}$ & me-histamine & Tiotidine & 10 & 0.5 & $>10000$ \\
\hline $\mathrm{H}_{4}$ & Clozapine & Histamine & 10 & 5 & $>10000$ \\
\hline$V_{1}$ & arg8-vaso & arg8-vaso & । & 0.5 & $>10000$ \\
\hline V2 & arg8-vaso & arg8-vaso & । & 0.5 & $>10000$ \\
\hline V3 & arg8-vaso & arg8-vaso & 1 & 0.5 & $>10000$ \\
\hline $\mathrm{CB}_{1}$ & CP-55934 & WIN-55,2I2 & 0.65 & 0.5 & $>10000$ \\
\hline Sigma-। & Haloperidol & Pentazocine & 3.6 & 3 & 5214 \\
\hline Sigma-2 & DTG & Haloperidol & 3 & 3.6 & $>10000$ \\
\hline II-Imidazoline & Naphazoline & lodo-clonidine & 0.5 & 0.25 & 2032 \\
\hline
\end{tabular}

Experiments were performed as described in Materials and Methods, using the radioligands and unlabelled reference ligands listed above. Data represent the mean of at least four separate experiments. All studies were performed with human cloned cDNAs except where specified; $r=$ rat cloned cDNA, *rat hypothalamic membranes.

\section{DISCUSSION}

Acute systemic treatment with PD149163, an NTR1 agonist that crosses the blood-brain barrier, activates both interneurons and pyramidal cells in the PFC of the rat, and is therefore consistent with the hypothesis that NT activates prefrontal cortical interneurons. 
Table 2 Effect of Vehicle or PDI49|63 on Core Body

Temperature

\begin{tabular}{lc}
\hline Treatment & Temperature $\left({ }^{\circ} \mathbf{C}\right)$ \\
\hline Vehicle & $36.5 \pm 0.2$ \\
PDI 49163 & \\
$0.25 \mathrm{mg} / \mathrm{kg}$ & $35.5 \pm 0.1 *$ \\
$2.5 \mathrm{mg} / \mathrm{kg}$ & $34.9 \pm 0.2^{*}$ \\
\hline
\end{tabular}

Data are presented as the mean $\left( \pm\right.$ SEM) core body temperature. ${ }^{*} p \leqslant 0.001$ relative to vehicle; ${ }^{\#} p \leqslant 0.05$ relative to $0.25 \mathrm{mg} / \mathrm{kg}$ PDI 49163 .

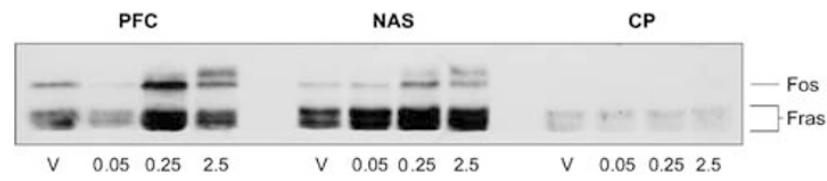

Figure I Representative immunoblots showing the effects of acute administration of PDI49163 or vehicle on forebrain Fos levels. PDI49|63 increased Fos expression in the PFC and NAS, but not the CP.

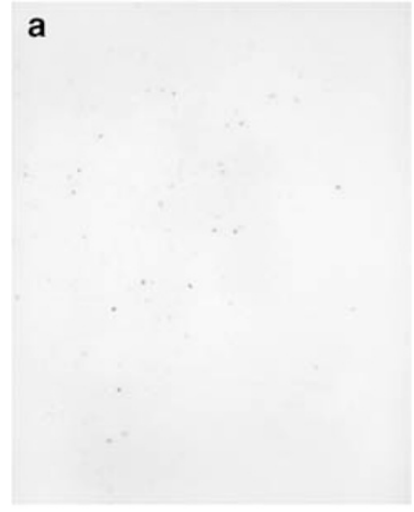

\section{Treatment vehicle \\ $0.25 \mathrm{mg} / \mathrm{kg}$} $2.5 \mathrm{mg} / \mathrm{kg}$

\section{b}

\begin{tabular}{c} 
Fos-li neurons $/ \mathrm{mm}^{2}$ \\
\hline $90.4 \pm 17.1$ \\
$253.0 \pm 58.9$ \\
$143.4 \pm 26.6$
\end{tabular}

Mean \pm SEM Fos-li neurons $/ \mathrm{mm}^{2}$

${ }^{*} \mathrm{p} \leq 0.05$

Figure 2 Effects of acute administration of PDI49|63 or vehicle on the density of Fos-li neurons in the PFC. Upper panel: Photomicrograph of Fos-li neurons in the PFC of an animal that received either vehicle (a) or $0.25 \mathrm{mg} / \mathrm{kg}$ PDI49/63 (b). Lower panel: Fos expression was highest in animals that received the low dose of $\mathrm{PDI} 49 \mid 63$. ${ }^{*} p \leqslant 0.05$ relative to vehicle.

\section{PD149163 Binds Selectively to NTR1}

PD149163 was originally described as a reduced amide bond NT(8-13) mimetic with central activity after peripheral administration (Feifel et al, 1999; Wustrow et al, 1995). Since the pharmacology of this compound had not been

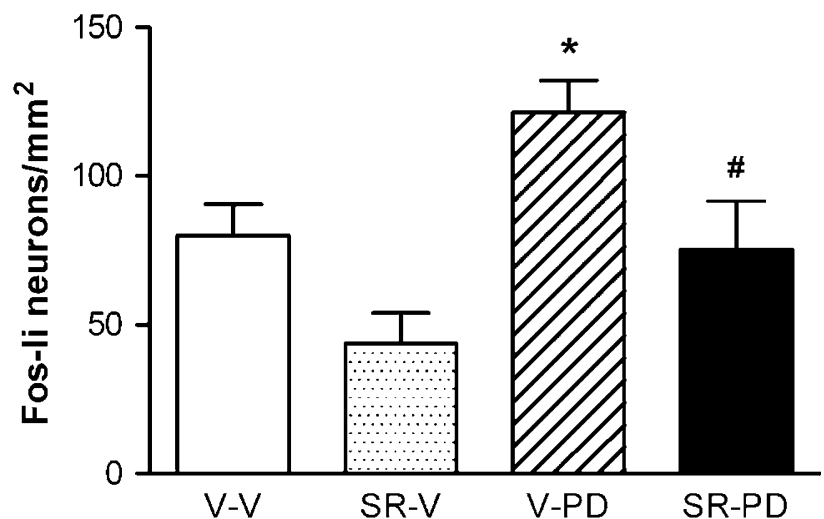

Figure 3 Effects of SR48692 pretreatment on PDI49/63-elicited Fos induction in the PFC. Pretreatment with the NTRI antagonist SR48692 (SR-PD) significantly attenuated the ability of PDI49I63 (V-PD) to induce Fos in the PFC. SR48692 had no significant effect when administered alone (SR-V). ${ }^{*} p \leqslant 0.05$ compared to vehicle $(V-V) ;{ }^{*} p \leqslant 0.05$ compared to $\mathrm{PD}|49| 63$
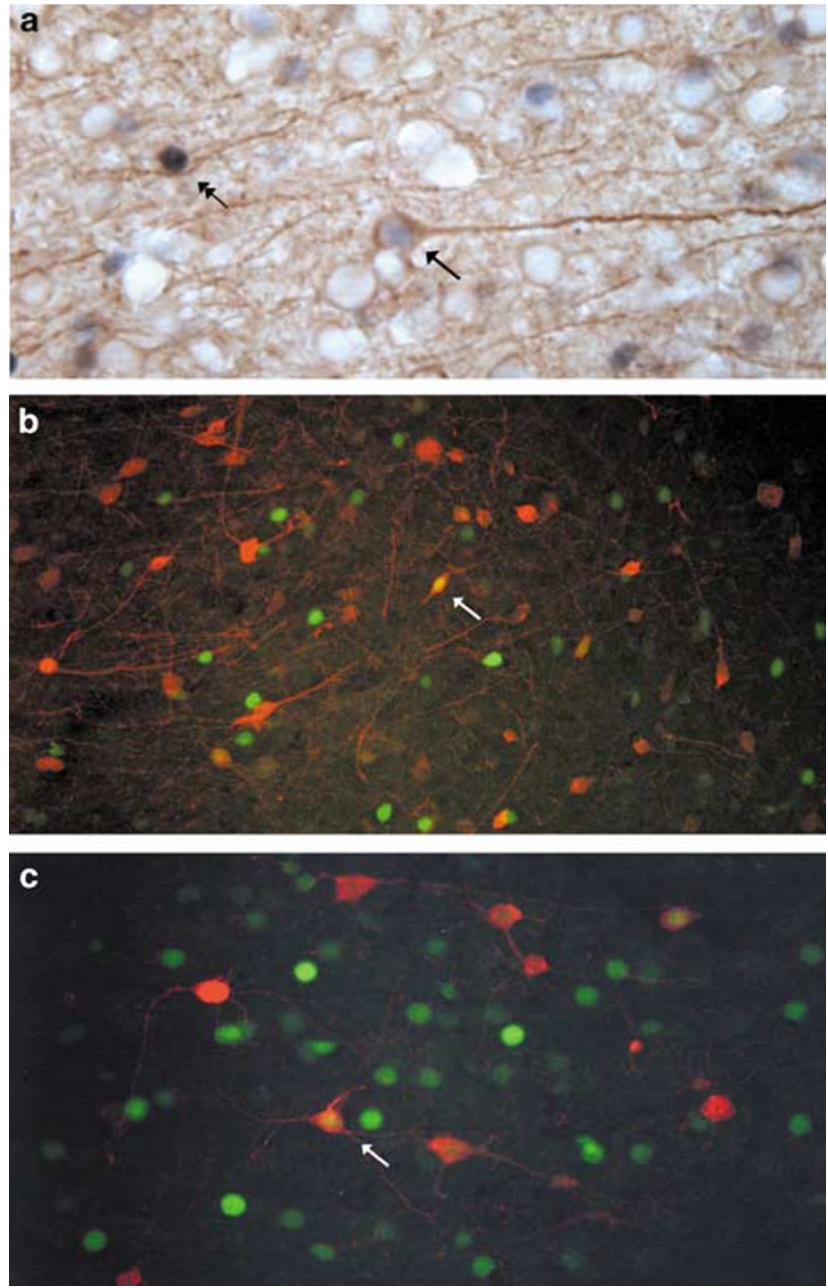

Figure 4 Photomicrographs showing the expression of Fos in PFC neurons. (a) Fos-li nucleus (gray-black) in a MAP-2-immunoreactive (brown reaction product) pyramidal cell. (b) Fos-li nucleus (green) in CB-expressing interneurons (red). (c) A PV-containing interneuron (red) expresses Foslike immunoreactivity (green). 

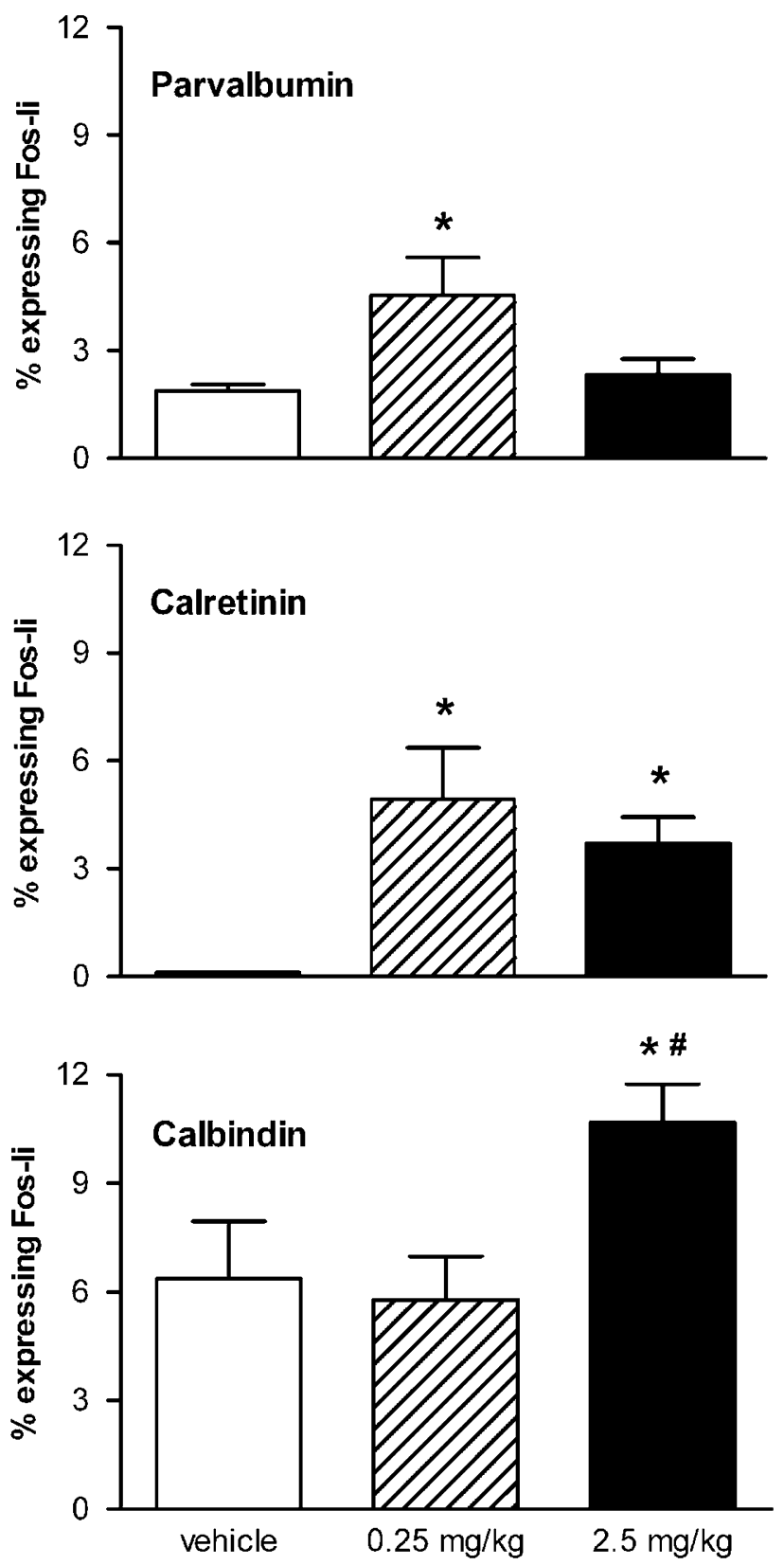

Figure 5 Effects of PDI49/63 on Fos expression in PV-, CR-, and CBcontaining interneurons in the PFC. The low dose of the NT agonist induced Fos in PV- and CR-containing interneurons, while only the high dose of PDI 49163 induced Fos in CB-containing interneurons. ${ }^{*} p \leqslant 0.05$ relative to vehicle; ${ }^{*} p \leqslant 0.05$ relative to $0.25 \mathrm{mg} / \mathrm{kg}$ PD 499 | 63 .

comprehensively profiled, we determined if PD149163 had significant affinity for various receptors, channels, or transporters. PD149163 had modest affinity for the cloned human NTR1 $\left(K_{\mathrm{i}}=159 \mathrm{nM}\right)$, but no measurable affinity for NTR2. In addition, PD149163 did not bind to any of a wide variety of other receptors, ion channels, or transporters tested. PD149163 displayed negligible affinity (>2000 nM) for the sigma-1- and imidazoline-1-binding sites.

\section{NT Agonist Activates Cortical Neurons}

Three NT receptors have been cloned. The high-affinity NTR1 and the low-affinity, levocabastine-sensitive NTR2
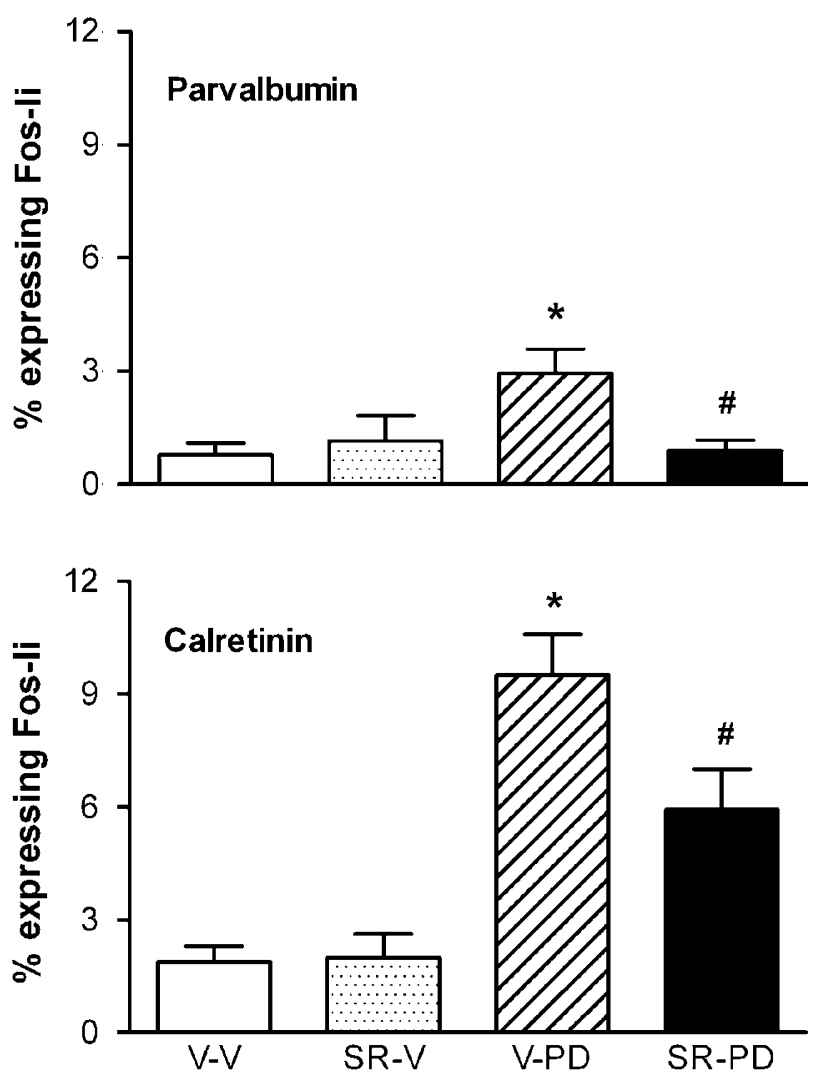

Figure 6 Effects of SR48692 pretreatment on PDI49I63-elicited Fos induction in PV- and CR-containing interneurons of the PFC. Pretreatment with SR48692 significantly attenuated PD I 49 I 63-induced Fos expression in both classes of interneurons. ${ }^{*} p \leqslant 0.05$ compared to vehicle; ${ }^{\#} p \leqslant 0.05$ compared to PDI49/63.

are G-protein-coupled receptors (Mazella et al, 1996; Tanaka et al, 1990). NTR3, which is identical to gp95/ sortilin, is a single transmembrane-spanning protein that is primarily localized to intracellular compartments (Sarret et al, 2003; Mazella et al, 1998).

Several lines of evidence suggest that the effects of PD149163 on Fos expression are mediated by NTR1. First, our analysis of PD149163 binding did not reveal any significant affinity of the agonist for NTR2 or other neurotransmitter receptors. Second, PD149163-elicited Fos induction was blocked by pretreatment with the NT antagonist SR48692, which has a high affinity $(3 \mathrm{nM})$ at NTR1 but an affinity at NTR2 that is two orders of magnitude lower (Mazella et al, 1996; Labbe-Jullie et al, 1995). Third, NTR1 is expressed on both prefrontal cortical interneurons and pyramidal cells (Petrie et al, 2002), consistent with the effects of PD149163 being mediated by NTR1. Finally, we observed that PD149163 dose-dependently decreased the core body temperature of rats. Administration of NT decreases body temperature through activation of NTR1 receptors, with decreases in core temperature not seen in NTR1 null mutant mice challenged with NT (Pettibone et al, 2002; Remaury et al, 2002).

Although SR48692 blocked PD149163-induced Fos expression in the PFC, the NT antagonist did not block PD149163-elicited hypothermia. This observation is consistent with the findings of Dubuc et al (1994), who noted 

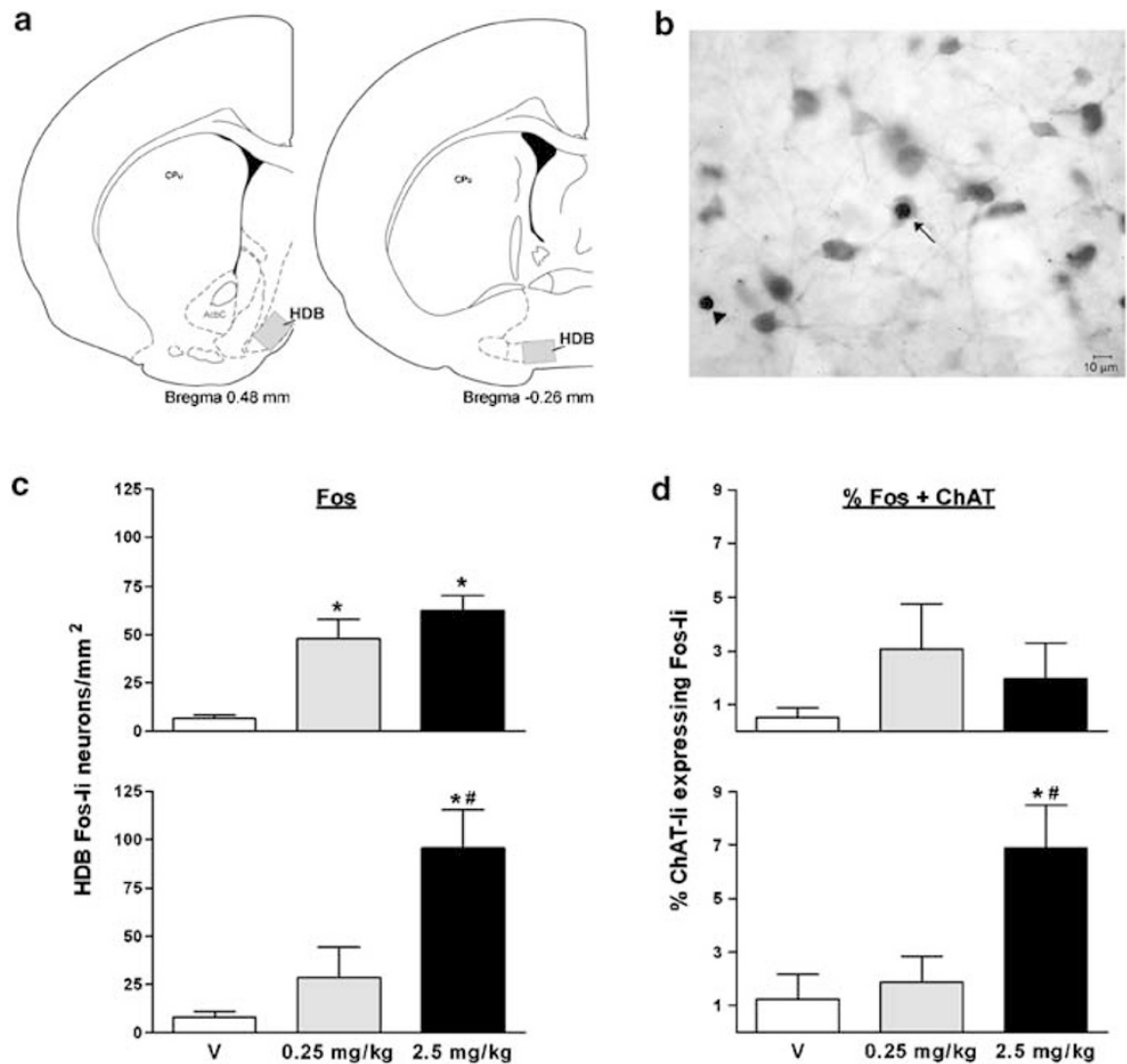

Figure 7 Effects of acute administration of PDI49/63 on the density of Fos-li neurons in the HDB. (a) Schematic illustration of the two areas of the HDB in which Fos-li neurons were counted. The red box indicates the approximate location of the counted cells. (b) Fos-li nucleus (arrowhead) in a ChAT-li cholinergic neuron (arrow). (c) PDI49/63 caused a dose-related increase in the density of Fos-li neurons in the rostral (upper panel) and caudal (lower panel) HDB. (d) Neurons immunoreactive for ChAT expressed Fos-li in the caudal (lower panel) but not rostral (upper panel) HDB. * $p \leqslant 0.05$ compared to vehicle, ${ }^{\#} p \leqslant 0.05$ compared to $0.25 \mathrm{mg} / \mathrm{kg}$ PD 149163.

that SR48692 had no effect on NT-induced hypothermia in rats or mice at the same doses that blocked NT-induced rotational behavior. Since NTR1 null mutant mice do not display a hypothermic response to NT, it is unclear as to why SR48692 does not antagonize PD149163-induced hypothermia. Previous reports have noted that nonpeptide NT antagonists do not block the full spectrum of NTmediated effects (Leonetti et al, 2002; Nalivaiko et al, 1998; Pinnock and Woodruff, 1994), leading to the suggestion that there may be an additional NT receptor that has not yet been cloned.

PD149163 binds weakly to both imidazoline-1 and sigma1 sites. The functional significance of these binding sites remains unclear (Langa et al, 2003; Eglen et al, 1998; Maurice and Lockhart, 1997). Although acute administration of the sigma ligand E-5842 has been shown to increase Fos in the medial PFC (Guitart and Farre, 1998), the observation that SR48692 blocks PD149163 effects on Fos expression argues for a role of NT receptors but not the sigma-1 site.

The hypothermia elicited by PD149163 may serve as a stressor. Because stress induces overall Fos expression in the PFC, it is possible that indirect stress effects account for the observed immediate-early gene response to PD149163. However, this is very unlikely because the high dose of the NT agonist, which elicited a lower body temperature than the lower dose, did not significantly increase overall Fos expression in the PFC.

\section{Effects of PD149163 on GABAergic Interneurons}

The ability of PD149163 to activate PFC interneurons is consistent with previous in vitro electrophysiology studies showing that NT increases GABA-mediated spontaneous postsynaptic potentials in the PFC (Audinat et al, 1989). NT has also been shown to activate GABAergic neurons in the striatum, with a resultant increase in extracellular GABA levels (Ferraro et al, 1998).

PD149163 significantly increased Fos expression in PVand CR-containing interneurons. However, the percentage of PV- and CR-containing cells in which Fos was induced was relatively low. Nonetheless, induction of Fos in the PV population of interneurons is likely to exert significant effects. PV interneurons are the most common class of interneuron in the cortex, comprising $60-70 \%$ of the total pool of GABAergic interneurons. PV-containing interneurons have a wide axonal arbor, in contrast to the narrow (columnar) axonal arbor of many other interneurons, and regulate hundreds of pyramidal cells. Moreover, chandelier cells, a morphological subtype of PV-containing interneuron, synapse onto the axon initial segment of pyramidal cells (Freund et al, 1983; Somogyi, 1977), placing them 
in a position to regulate powerfully pyramidal cell activity and hence overall cortical output. Thus, it is likely that activation of even a small percentage of PV-containing cells will exert a relatively broad effect on cortical function. Additional electrophysiological studies will be required to elucidate the physiological correlates of PD149163-induced Fos expression in the PFC.

\section{Dose-Related Induction of Fos in PFC GABA Interneurons}

We observed that a low but not high dose of PD149163 induced Fos in PFC neurons, irrespective of the type of neuron; a similar dose-related effect emerged upon examination of Fos in PV-containing interneurons. Previous reports have also noted an inverted U-shaped doseresponse relationship of NT agonists on baseline and amphetamine-disrupted prepulse inhibition of the startle response (Shilling et al, 2003; Feifel et al, 1997). The mechanisms that account for such dose-dependent effects of NT agonists are not known. It is possible that differential activation of pre- and postsynaptic NT receptors may contribute to the dose-related effects of PD149163 on Fos expression in PFC neurons, including PV-containing interneurons.

The most parsimonious model accounting for the ability of systemically administered PD149163 to increase PFC Fos is through direct actions of the agonist on cortical cells. NTR1 mRNA and protein have been observed in PFC neurons, particularly those in the deep layers of the infralimbic and prelimbic cortices (Alexander and Leeman, 1998; Boudin et al, 1996; Nicot et al, 1994). Preliminary data suggest that both interneurons and pyramidal cells express NTR1 in this region (Petrie et al, 2002).

We cannot, however, exclude the possibility that transsynaptic actions reflecting an initial action of the NT agonist on some afferent population to the PFC is responsible for the increase in Fos expression in PFC interneurons. We therefore assessed if PD149163 increased Fos expression in basal forebrain neurons, including cholinergic cells of the basal forebrain that project to the PFC. These cholinergic neurons express NTR1 and are depolarized in response to NT application (Cape et al, 2000; Matthews, 1999; Farkas et al, 1994).

We observed that PD149163 increased Fos expression in neurons, irrespective of phenotype, in both the rostral and caudal parts of the HDB. In contrast, the effect of PD149163 on cholinergic cells in the HDB was observed only in the caudal HDB. It is interesting to note that those HDB cholinergic cells that project to the PFC are most dense in the caudal HDB (Gaykema et al, 1991, 1990; Luiten et al, 1987), suggesting that the NT agonist may be selectively activating those cholinergic cells that innervate the PFC.

The high $(2.5 \mathrm{mg} / \mathrm{kg})$ dose of PD149163 increased Fos expression in the basal forebrain cholinergic cells. We observed a significant increase in the percentage of CRcontaining PFC interneurons expressing Fos at the high dose, whereas the lower dose activated PV-li interneurons. This parallel suggests that the actions of PD149163 at the higher dose on $\mathrm{CR}$ interneurons may reflect trans-synaptic activation from basal forebrain cholinergic cells, but that the induction of Fos in PV cells, the major type of cortical interneuron in the rat, may be a direct action.

\section{Implications}

Several studies have reported that cerebrospinal fluid levels of NT are reduced in schizophrenic patients, particularly those with prominent negative symptoms (Garver et al, 1991; Lindstrom et al, 1988; Widerlov et al, 1982); NT levels tend to normalize in response to antipsychotic drug (APD) treatment (Sharma et al, 1997; Breslin et al, 1994). APDs exert behavioral effects similar to those seen in animals receiving central administration of NT (see Kinkead et al, 1999). Accordingly, considerable interest has been generated in NT as an endogenous APD (Nemeroff, 1980) with potential therapeutic value in schizophrenia.

The regional pattern of Fos induction by PD149163 is similar to that of an atypical APD, with pronounced effects in the PFC but not dorsolateral striatum. Activation of both prefrontal cortical interneurons and pyramidal cells is consistent with the actions of atypical APDs such as clozapine (Deutch and Duman, 1996). This is particularly interesting because the number and/or function of GABA interneurons in the PFC may be compromised in schizophrenia (Hashimoto et al, 2003; Benes et al, 2000; Lewis et al, 1999; Akbarian et al, 1995). Our data suggest that NT agonists activate PFC interneurons and could thereby compensate for a prefrontal cortical GABAergic deficit in schizophrenia.

GABAergic neurons in primate species receive DA inputs (Sesack et al, 1995b). However, in contrast to rodents, the laminar distributions of DA and NT axons in primates differ, suggesting that the two transmitters are not colocalized in the PFC of primates, including humans (Gaspar et al, 1990). In situ hybridization analysis has, however, revealed that tyrosine hydroxylase and NT mRNAs are colocalized in some ventral tegmental area neurons (Bean et al, 1992). Moreover, it is possible that NT may not be present at detectable levels under basal conditions, but may be rapidly induced and become obvious after appropriate challenges (Deutch and Zahm, 1992; Merchant et al, 1991; Eggerman and Zahm, 1988). Finally, NT is clearly present in axons of the human PFC, regardless of NT presence in dopaminergic axons, and thus NT may be positioned to activate GABAergic neurons and thereby potentially ameliorate negative symptoms and cognitive deficits arising from PFC.

\section{ACKNOWLEDGEMENTS}

We thank Yueli Zhang for technical assistance and Tamara Altman Geraci for help in preparing the figures. We appreciate the help of the Chemical Synthesis Branch of NIMH in synthesizing and providing us with PD149163. Sanofi Recherche kindly supplied us with SR48692, and we thank Dr Michael Iadorola for the Fos antiserum. This work was supported in part by Grants MH-12972 (KAP), MH57995 and MH-45124 (AYD), KO2MH01366 (BLR), the National Parkinson's Foundation Center for Excellence at Vanderbilt University, and the NIMH Psychoactive Drug Screening Program (http://pdsp.cwru.edu/). 


\section{REFERENCES}

Akbarian S, Kim JJ, Potkin SG, Hagman JO, Tafazzoli A, Bunney Jr WE et al (1995). Gene expression for glutamic acid decarboxylase is reduced without loss of neurons in prefrontal cortex of schizophrenics. Arch Gen Psychiatry 52: 258-266.

Alexander MJ, Leeman SE (1998). Widespread expression in adult rat forebrain of mRNA encoding high-affinity neurotensin receptor. J Comp Neurol 402: 475-500.

Audinat E, Hermel JM, Crepel F (1989). Neurotensin-induced excitation of neurons of the rat's frontal cortex studied intracellularly in vitro. Exp Brain Res 78: 358-368.

Bean AJ, Dagerlind A, Hokfelt T, Dobner PR (1992). Cloning of human neurotensin/neuromedin $\mathrm{N}$ genomic sequences and expression in the ventral mesencephalon of schizophrenics and age/sex matched controls. Neuroscience 50: 259-268.

Bean AJ, Roth RH (1992). Dopamine-neurotensin interactions in mesocortical neurons. Evidence from microdialysis studies. Ann NY Acad Sci 668: 43-53.

Benes FM, Todtenkopf MS, Logiotatos P, Williams M (2000). Glutamate decarboxylase(65)-immunoreactive terminals in cingulate and prefrontal cortices of schizophrenic and bipolar brain. J Chem Neuroanat 20: 259-269.

Bissette G, Nemeroff CB, Loosen PT, Prange Jr AJ, Lipton MA (1976). Hypothermia and intolerance to cold induced by intracisternal administration of the hypothalamic peptide neurotensin. Nature 262: 607-609.

Boudin H, Pelaprat D, Rostene W, Beaudet A (1996). Cellular distribution of neurotensin receptors in rat brain: immunohistochemical study using an antipeptide antibody against the cloned high affinity receptor. J Comp Neurol 373: 76-89.

Breslin NA, Suddath RL, Bissette G, Nemeroff CB, Lowrimore P, Weinberger DR (1994). CSF concentrations of neurotensin in schizophrenia: an investigation of clinical and biochemical correlates. Schizophr Res 12: 35-41.

Cape EG, Manns ID, Alonso A, Beaudet A, Jones BE (2000). Neurotensin-induced bursting of cholinergic basal forebrain neurons promotes gamma and theta cortical activity together with waking and paradoxical sleep. J Neurosci 20: $8452-8461$.

Cohen JD, Braver TS, Brown JW (2002). Computational perspectives on dopamine function in prefrontal cortex. Curr Opin Neurobiol 12: 223-229.

DeFelipe J (1997). Types of neurons, synaptic connections and chemical characteristics of cells immunoreactive for calbindinD28K, parvalbumin and calretinin in the neocortex. J Chem Neuroanat 14: 1-19.

DeFelipe J, Farinas I (1992). The pyramidal neuron of the cerebral cortex: morphological and chemical characteristics of the synaptic inputs. Prog Neurobiol 39: 563-607.

Deutch AY, Duman RS (1996). The effects of antipsychotic drugs on Fos protein expression in the prefrontal cortex: cellular localization and pharmacological characterization. Neuroscience 70: 377-389.

Deutch AY, Zahm DS (1992). The current status of neurotensindopamine interactions. Issues and speculations. Ann NY Acad Sci 668: 232-252.

Dubuc I, Costentin J, Terranova JP, Barnouin MC, Soubrie P, Le Fur G et al (1994). The nonpeptide neurotensin antagonist, SR 48692 , used as a tool to reveal putative neurotensin receptor subtypes. Br J Pharmacol 112: 352-354.

Eggerman KW, Zahm DS (1988). Numbers of neurotensinimmunoreactive neurons selectively increased in rat ventral striatum following acute haloperidol administration. Neuropeptides 11: 125-132.

Eglen RM, Hudson AL, Kendall DA, Nutt DJ, Morgan NG, Wilson VG et al (1998). 'Seeing through a glass darkly': casting light on imidazoline 'I' sites. Trends Pharmacol Sci 19: 381-390.
Farkas RH, Nakajima S, Nakajima Y (1994). Neurotensin excites basal forebrain cholinergic neurons: ionic and signal-transduction mechanisms. Proc Natl Acad Sci USA 91: 2853-2857.

Feifel D, Melendez G, Shilling PD (2003). A systemically administered neurotensin agonist blocks disruption of prepulse inhibition produced by a serotonin-2A agonist. Neuropsychopharmacology 28: 651-653.

Feifel D, Minor KL, Dulawa S, Swerdlow NR (1997). The effects of intra-accumbens neurotensin on sensorimotor gating. Brain Res 760: $80-84$.

Feifel D, Reza TL, Wustrow DJ, Davis MD (1999). Novel antipsychotic-like effects on prepulse inhibition of startle produced by a neurotensin agonist. J Pharmacol Exp Ther 288: 710-713.

Ferraro L, Antonelli T, O'Connor WT, Fuxe K, Soubrie P, Tanganelli S (1998). The striatal neurotensin receptor modulates striatal and pallidal glutamate and GABA release: functional evidence for a pallidal glutamate-GABA interaction via the pallidal-subthalamic nucleus loop. J Neurosci 18: 6977-6989.

Freund TF, Martin KA, Smith AD, Somogyi P (1983). Glutamate decarboxylase-immunoreactive terminals of Golgi-impregnated axoaxonic cells and of presumed basket cells in synaptic contact with pyramidal neurons of the cat's visual cortex. J Comp Neurol 221: 263-278.

Gabbott PL, Dickie BG, Vaid RR, Headlam AJ, Bacon SJ (1997). Local-circuit neurones in the medial prefrontal cortex (areas 25, 32 and 24b) in the rat: morphology and quantitative distribution. J Comp Neurol 377: 465-499.

Garver DL, Bissette G, Yao JK, Nemeroff CB (1991). Relation of CSF neurotensin concentrations to symptoms and drug response of psychotic patients. Am J Psychiatry 148: 484-488.

Gaspar P, Berger B, Febvret A (1990). Neurotensin innervation of the human cerebral cortex: lack of colocalization with catecholamines. Brain Res 530: 181-195.

Gaykema RP, Gaal G, Traber J, Hersh LB, Luiten PG (1991). The basal forebrain cholinergic system: efferent and afferent connectivity and long-term effects of lesions. Acta Psychiatr Scand Suppl 366: 14-26.

Gaykema RP, Luiten PG, Nyakas C, Traber J (1990). Cortical projection patterns of the medial septum-diagonal band complex. J Comp Neurol 293: 103-124.

Goldman-Rakic PS (2002). The 'psychic cell' of Ramon y Cajal. Prog Brain Res 136: 427-434.

Gritti I, Mainville L, Mancia M, Jones BE (1997). GABAergic and other noncholinergic basal forebrain neurons, together with cholinergic neurons, project to the mesocortex and isocortex in the rat. J Comp Neurol 383: 163-177.

Grobin AC, Deutch AY (1998). Dopaminergic regulation of extracellular gamma-aminobutyric acid levels in the prefrontal cortex of the rat. J Pharmacol Exp Ther 285: 350-357.

Guitart X, Farre AJ (1998). The effect of E-5842, a sigma receptor ligand and potential atypical antipsychotic, on Fos expression in rat forebrain. Eur J Pharmacol 363: 127-130.

Hashimoto T, Volk DW, Eggan SM, Mirnics K, Pierri JN, Sun Z et al (2003). Gene expression deficits in a subclass of GABA neurons in the prefrontal cortex of subjects with schizophrenia. J Neurosci 23: 6315-6326.

Hernandez-Lopez S, Tkatch T, Perez-Garci E, Galarraga E, Bargas $\mathrm{J}$, Hamm $\mathrm{H}$ et al (2000). D2 dopamine receptors in striatal medium spiny neurons reduce L-type $\mathrm{Ca}^{2+}$ currents and excitability via a novel PLC[beta]1-IP3-calcineurin-signaling cascade. J Neurosci 20: 8987-8995.

Huff RM (1996). Signal transduction pathways modulated by the D2 subfamily of dopamine receptors. Cell Signal 8: 453-459.

Kinkead B, Binder EB, Nemeroff CB (1999). Does neurotensin mediate the effects of antipsychotic drugs? Biol Psychiatry 46: $340-351$. 
Kotecha SA, Oak JN, Jackson MF, Perez Y, Orser BA, Van Tol HH et al (2002). A D2 class dopamine receptor transactivates a receptor tyrosine kinase to inhibit NMDA receptor transmission. Neuron 35: 1111-1122.

Labbe-Jullie C, Botto JM, Mas MV, Chabry J, Mazella J, Vincent JP et al (1995). [3H]SR 48692, the first nonpeptide neurotensin antagonist radioligand: characterization of binding properties and evidence for distinct agonist and antagonist binding domains on the rat neurotensin receptor. Mol Pharmacol 47: 1050-1056.

Langa F, Codony X, Tovar V, Lavado A, Gimenez E, Cozar P et al (2003). Generation and phenotypic analysis of sigma receptor type I (sigma 1) knockout mice. Eur J Neurosci 18: 2188-2196.

Le Moine C, Gaspar P (1998). Subpopulations of cortical GABAergic interneurons differ by their expression of D1 and D2 dopamine receptor subtypes. Brain Res Mol Brain Res 58: 231-236.

Leonetti M, Brun P, Sotty F, Steinberg R, Soubrie P, Bert L et al (2002). The neurotensin receptor antagonist SR 142948A blocks the efflux of dopamine evoked in nucleus accumbens by neurotensin ejection into the ventral tegmental area. Naunyn Schmiedebergs Arch Pharmacol 365: 427-433.

Lewis DA, Pierri JN, Volk DW, Melchitzky DS, Woo TU (1999). Altered GABA neurotransmission and prefrontal cortical dysfunction in schizophrenia. Biol Psychiatry 46: 616-626.

Lindstrom LH, Widerlov E, Bisette G, Nemeroff C (1988). Reduced CSF neurotensin concentration in drug-free schizophrenic patients. Schizophr Res 1: 55-59.

Lowry O, Rosebrough N, Farr A, Randall R (1951). Protein measurement with the Folin phenol reagent. J Biol Chem 193: 265-275.

Luiten PG, Gaykema RP, Traber J, Spencer Jr DG (1987). Cortical projection patterns of magnocellular basal nucleus subdivisions as revealed by anterogradely transported Phaseolus vulgaris leucoagglutinin. Brain Res 413: 229-250.

Matthews RT (1999). Neurotensin depolarizes cholinergic and a subset of non-cholinergic septal/diagonal band neurons by stimulating neurotensin-1 receptors. Neuroscience 94: 775-783.

Maurice T, Lockhart BP (1997). Neuroprotective and anti-amnesic potentials of sigma (sigma) receptor ligands. Prog Neuropsychopharmacol Biol Psychiatry 21: 69-102.

Mazella J, Botto JM, Guillemare E, Coppola T, Sarret P, Vincent JP (1996). Structure, functional expression, and cerebral localization of the levocabastine-sensitive neurotensin/neuromedin $\mathrm{N}$ receptor from mouse brain. J Neurosci 16: 5613-5620.

Mazella J, Zsurger N, Navarro V, Chabry J, Kaghad M, Caput D et al (1998). The $100-\mathrm{kDa}$ neurotensin receptor is gp95/sortilin, a non-G-protein-coupled receptor. J Biol Chem 273: 26273-26276.

Merchant KM, Miller MA, Ashleigh EA, Dorsa DM (1991). Haloperidol rapidly increases the number of neurotensin mRNA-expressing neurons in neostriatum of the rat brain. Brain Res 540: 311-314.

Miller EK, Freedman DJ, Wallis JD (2002). The prefrontal cortex: categories, concepts and cognition. Philos Trans $R$ Soc Lond B 357: 1123-1136.

Nalivaiko E, Michaud JC, Soubrie P, Le Fur G (1998). Electrophysiological evidence for putative subtypes of neurotensin receptors in guinea-pig mesencephalic dopaminergic neurons. Neuroscience 86: 799-811.

Nemeroff CB (1980). Neurotensin: perchance an endogenous neuroleptic? Biol Psychiatry 15: 283-302.

Nicot A, Rostene W, Berod A (1994). Neurotensin receptor expression in the rat forebrain and midbrain: a combined analysis by in situ hybridization and receptor autoradiography. J Comp Neurol 341: 407-419.

Petrie KA, Schmidt DE, Deutch AY (2002). D2-elicited GABA release in the prefrontal cortex is mediated by high-affinity neurotensin-1 receptors. Society for Neuroscience Abstracts, Program No. 63.8.

Pettibone DJ, Hess JF, Hey PJ, Jacobson MA, Leviten M, Lis EV et al (2002). The effects of deleting the mouse neurotensin receptor NTR1 on central and peripheral responses to neurotensin. J Pharmacol Exp Ther 300: 305-313.

Pinnock RD, Woodruff GN (1994). The non-peptide neurotensin receptor antagonist SR48692 is not a potent antagonist of neurotensin(8-13) responses of rat substantia nigra neurones in vitro. Neurosci Lett 172: 175-178.

Quinn JP, Takimoto M, Iadarola M, Holbrook N, Levens D (1989). Distinct factors bind the AP-1 consensus sites in gibbon ape leukemia virus and simian virus 40 enhancers. J Virol 63: 1737-1742.

Remaury A, Vita N, Gendreau S, Jung M, Arnone M, Poncelet M et al (2002). Targeted inactivation of the neurotensin type 1 receptor reveals its role in body temperature control and feeding behavior but not in analgesia. Brain Res 953: 63-72.

Rogers JH (1992). Immunohistochemical markers in rat cortex: co-localization of calretinin and calbindin-D28k with neuropeptides and GABA. Brain Res 587: 147-157.

Sarret P, Krzywkowski P, Segal L, Nielsen MS, Petersen CM, Mazella J et al (2003). Distribution of NTS3 receptor/sortilin mRNA and protein in the rat central nervous system. J Comp Neurol 461: 483-505.

Seguela P, Watkins KC, Descarries L (1988). Ultrastructural features of dopamine axon terminals in the anteromedial and the suprarhinal cortex of adult rat. Brain Res 442: 11-22.

Sesack SR, Bressler CN, Lewis DA (1995a). Ultrastructural associations between dopamine terminals and local circuit neurons in the monkey prefrontal cortex: a study of calretininimmunoreactive cells. Neurosci Lett 200: 9-12.

Sesack SR, Snyder CL, Lewis DA (1995b). Axon terminals immunolabeled for dopamine or tyrosine hydroxylase synapse on GABA-immunoreactive dendrites in rat and monkey cortex. J Comp Neurol 363: 264-280.

Shapiro DA, Renock S, Arrington E, Chiodo LA, Liu LX, Sibley DR et al (2003). Aripiprazole, a novel atypical antipsychotic drug with a unique and robust pharmacology. Neuropsychopharmacology 28: 1400-1411.

Sharma RP, Janicak PG, Bissette G, Nemeroff CB (1997). CSF neurotensin concentrations and antipsychotic treatment in schizophrenia and schizoaffective disorder. Am J Psychiatry 154: 1019-1021.

Shilling PD, Richelson E, Feifel D (2003). The effects of systemic NT69L, a neurotensin agonist, on baseline and drug-disrupted prepulse inhibition. Behav Brain Res 143: 7-14.

Somogyi P (1977). A specific 'axo-axonal' interneuron in the visual cortex of the rat. Brain Res 136: 345-350.

Studler JM, Kitabgi P, Tramu G, Herve D, Glowinski J, Tassin JP (1988). Extensive co-localization of neurotensin with dopamine in rat meso-cortico-frontal dopaminergic neurons. Neuropeptides 11: 95-100.

Tanaka K, Masu M, Nakanishi S (1990). Structure and functional expression of the cloned rat neurotensin receptor. Neuron 4: 847-854.

van Eden CG, Hoorneman EM, Buijs RM, Matthijssen MA, Geffard M, Uylings HB (1987). Immunocytochemical localization of dopamine in the prefrontal cortex of the rat at the light and electron microscopical level. Neuroscience 22: 849-862.

Verney C, Alvarez C, Geffard M, Berger B (1990). Ultrastructural double-labelling study of dopamine terminals and GABAcontaining neurons in rat anteromedial cerebral cortex. Eur J Neurosci 2: 960-972.

Widerlov E, Lindstrom LH, Besev G, Manberg PJ, Nemeroff CB, Breese GR et al (1982). Subnormal CSF levels of neurotensin in a subgroup of schizophrenic patients: normalization after neuroleptic treatment. Am J Psychiatry 139: 1122-1126. 
Wolf ME, Roth RH (1987). Dopamine neurons projecting to the medial prefrontal cortex possess releasemodulating autoreceptors. Neuropharmacology 26: 1053-1059.

Wustrow DJ, Davis MD, Akunne HC, Corbin AE, Wiley JN, Wise LD et al (1995). Reduced amide bond neurotensin(8-13) mimetics with potent in vivo activity. Bioorg Med Chem 5: 997-1002.

Yamada M, Watson MA, Richelson E (1993). Neurotensin stimulates cyclic AMP formation in CHO-rNTR-10 cells expressing the cloned rat neurotensin receptor. Eur J Pharmacol 244: 99-101. 